AGREGAT: Jurnal Ekonomi dan Bisnis

Vol. 3, No. 1, Maret 2019

http://journal.uhamka.ac.id/index.php/agregat

p-ISSN: 2549-5658 e-ISSN: 2549-7243

DOI: $10.22236 /$ agregat_vol3/is1pp 17-24

Hal 17-16

\title{
THE VALUE-ADDED ANALYSIS OF INTELLECTUAL CAPITAL FOR BANKING FINANCIAL PERFORMANCE
}

\author{
Tupi Setyowati ${ }^{1}$, Jamilah ${ }^{2}$ \\ ${ }^{12}$ University of Muhammadiyah of Prof. DR. HAMKA, Jakarta, Indonesia \\ Email: tupi_setyowati@uhamka.ac.id
}

Diterima: 30 Januari 2019; Direvisi: 7 Februari 2019; Disetujui: 25 Februari 2019

\begin{abstract}
This study was conducted to see how intellectual capital (IC) affects company performance (ROA) by entering the size variable in its calculations. This study also analyzes how much financial performance changes occur as an effect of the efficiency of the use of capital employees (CEE), the efficiency of using Structural Capital (SCE), and the partial efficiency of using Human Capital (HCE). Research was conducted on conventional banking in Indonesia for the period 2013 - 2017. The research data was obtained from the official website of the Indonesia Stock Exchange (IDX). This study found that VAIC had a significant positive effect on ROA, and from the three IC components it turned out that the CEE component had the greatest influence on ROA
\end{abstract}

Keywords: Intellectual Capital, ROA, Size, Banking.

\begin{abstract}
Abstrak
Penelitian ini dilakukan untuk melihat bagaimana Intelectual Capital (IC) mempengaruhi kinerja perusahaan (ROA) dengan memasukkan variabel size dalam perhitungannya. Penelitian ini juga menganalisis berapa banyak perubahan kinerja keuangan terjadi sebagai efek dari efisiensi penggunaan modal karyawan (CEE), efisiensi menggunakan Structural Capital (SCE), dan efisiensi parsial menggunakan Human Capital (HCE). Penelitian dilakukan pada perbankan konvensional di Indonesia untuk periode 2013 - 2017. Data penelitian diperoleh dari situs web resmi Bursa Efek Indonesia (BEI). Studi ini menemukan bahwa VAIC memiliki efek positif yang signifikan terhadap ROA, dan dari ketiga komponen IC ternyata komponen CEE memiliki pengaruh terbesar pada ROA.
\end{abstract}

Kata Kunci: Intellectual Capital, ROA, Size, Perbankan. 


\section{INTRODUCTION}

Information development makes business patterns begin to change. The power of globalization, financial innovation and progress information technology guide banks to follow aggressive business strategies to reinforce their bottom-line (Saif, 2018). What we are experiencing now is a dramatic shift from material sources to knowledge, from hardware to software. At the time of expansion and growth based on new knowledge of "factors of production" which have replaced energy from artificial and natural energy to a certain extent which aims to replace routine work and finally physical capital (Pulic, 1998).

Technological advances have changed the financial services industry very quickly. Such progress is not accompanied by regulation and understanding of technology and its impact on the financial sector (Lucey et al., 2018).

According to Edvinson Intellectual capital is an intangible asset that is explicitly not contained in financial statements but has an impact on financial performance and is a relationship between employee, idea and information (Edvinson, 2001). Intellectual Capital is an asset or non-monetary source without physical substance which is a fundamental factor in the process of creating corporate value. Knowledge-based companies depend primarily on the types of assets for value creation and their competitive advantage. The empirical results show that companies that have better intel-
Tupi Setyowati 18 lectual capital efficiency and are able to manage intellectual capital efficiently will reach the level of efficiency according to the targets set (Mondal \& Ghosh, 2015).

The debate about the results of research related to how the influence of intellectual capital on banking performance is still warm. Nazif (Ozkan, Cakan, \& Kayacan, 2017) analyzed 44 Operational Banks in Turkey between 2005 and 2014, in his research found that Intellectual Capital had a positive impact on company performance which in this study proxyed with ROA. The performance of the intellectual capital of the Turkish banking sector is generally influenced by the efficiency of Human Capital (human capital efficiency HCE). Irina (Berzkalne \& Zelgalve, 2014) conducted a study of 65 companies listed on the Baltic during the period 2005 to 2011 . This study used correlation analysis to provide an empirical investigation of the impact of intellectual capital on firm value. This study found that capital efficiency and efficient use of capital can still be used to calculate intellectual capital, the efficiency of structural capital is not significant in terms of intellectual capital and firm value. Antonio (Meles, Porzio, Sampagnaro, \& Verdoliva, 2016), Mahfoudh Abdul Karem (Al-Musali \& Ismail, 2014), Silvia (Sumedrea, 2013) support Nazif and Irina research that Intellectual Capital plays a very positive role or role in performance company. The effect on financial performance is positive and significant when the analysis involves the long term (Santos, Basso, \& Kimura, 2018).

A lot of literature review is done by looking at intellectual factors one by one to see how 
DOI: 10.22236/agregat_vol3/is1pp17-24

Hal 19

the impact of each variable on the value of the company. Research conducted by Joshi (Joshi, Cahill, \& Sidhu, 2010) tested the performance of ICs from 11 Australian-owned banks that had good performance for the period 2005-2007. Elders Rural Bank, a small bank in terms of total assets, shareholder equity and the number of employees is the best performing bank among Australian-owned

banks followed by four major banks operating in Australia. The HCE relationship is significant and has a considerable impact on bank efficiency in value creation. Efficiency in utilizing $\mathrm{HC}$ makes Bank Australia able to show high performance. Bank performance in terms of CEE and SCE has little or no impact on efficiency. the bank as a whole and its value creation (Joshi, Cahill, \& Sidhu, 2010).

Table 1. GAP Research

\begin{tabular}{|l|l|l|}
\hline Title & Authors & Finding \\
\hline $\begin{array}{l}\text { Effect of Human Capital } \\
\text { on Company Performance }\end{array}$ & (Ozkan et al., 2017) & $\begin{array}{l}\text { HCE positively affects the bank's finan- } \\
\text { cial performance }\end{array}$ \\
\cline { 2 - 3 } & $\begin{array}{l}\text { (Hashim, Osman, \& } \\
\text { Alhabshi, 2015) }\end{array}$ & $\begin{array}{l}\text { HC individually is not significant to- } \\
\text { wards ROA }\end{array}$ \\
\cline { 2 - 4 } $\begin{array}{l}\text { (Al-Musali \& Is- } \\
\text { mail, 2014) }\end{array}$ & $\begin{array}{l}\text { Human Capital does not have full poten- } \\
\text { tial to improve company performance }\end{array}$ \\
\hline \multirow{2}{*}{$\begin{array}{l}\text { Effect of Structural Cap- } \\
\text { mance }\end{array}$} & $\begin{array}{l}\text { (Ozkan et al., 2017) } \\
\text { SCompany Perfor- }\end{array}$ & $\begin{array}{l}\text { SCE does not have a significant effect on } \\
\text { bank financial performance }\end{array}$ \\
\cline { 2 - 4 } & $\begin{array}{l}\text { (Hashim et al., } \\
\text { 2015) }\end{array}$ & $\begin{array}{l}\text { SC individually is not significant for per- } \\
\text { formance }\end{array}$ \\
\cline { 2 - 4 } & $\begin{array}{l}\text { (Al-Musali \& Is- } \\
\text { mail, 2014) }\end{array}$ & $\begin{array}{l}\text { Structural Capital does not have full po- } \\
\text { tential to improve company performance }\end{array}$ \\
\hline
\end{tabular}

Referring to research conducted by Pulic (Pulic, 1998, 2004), (Ullum, 2016), (ullum, 2017), (Ozkan, Cakan, \& Kayacan, 2017) the efficiency of intellectual capital is measured using VAIC variables, namely variables to measure the efficiency of intellectual use capital by looking at the added value obtained by the company from the intellectual use. Value added (VA) is obtained by adding operational costs $(\mathrm{O}), \mathrm{D}$ (depreciation), employee costs, and amortization (A). VAIC is the sum of the efficient use of human capital (HCE), the efficiency of capital employed (CEE) and the efficiency of the use of structural capital (SCE).

Human Capital Employee, is the efficient use of human capital obtained by dividing human capital with value added ( $\mathrm{HCE}=\mathrm{HC}$ ( VA) where $\mathrm{HC}$ is the total salaries and wages. Structural Capital Employed is obtained by dividing structural capital with value added $(\mathrm{SCE}=\mathrm{SC} / \mathrm{VA})$ where SC is VA-HC. CEE is obtained by dividing CE by value added $(\mathrm{CEE}=\mathrm{CE} / \mathrm{VA})$ while $\mathrm{CE}$ according to (Pulic, 2004) and (Ullum, 2016, 2017) is the book value of total assets. 


\section{RESEARCH METHODS}

The data processed is banking data in Indonesia for the period 2010 to 2017. The dependent variable in this study is the bank's financial performance using a ROA proxy. ROA is the main measure for calculating bank profitability (Dietrich \& Wanzenried, 2011; Ozkan et al., 2017; Pasiouras \& Kosmidou, 2007).

The independent variables in this study are Value added intellectual coefficient (VAIC) developed by (Pulic, 1998) to measure the efficiency of intellectual capital from bank financial performance. VAIC is a measuring instrument used to see the level of efficiency of banks. The higher the value of VAIC, the more efficient the company or the added value generated from each of the costs incurred is higher. The intellectual capital component has a different role to bank profitability. This study studies how intellectual capital factors consisting of human capital, employee capital and structural capital that most influence bank financial performance (ROA).

Research conducted (Ozkan, Cakan, \& Kayacan, 2017) found that company size variables greatly influence the efficiency of the use of intellectual capital. Based on the results of these studies, the authors include variable size banks as additional variables in this study.

The methodology in this study begins
Tupi Setyowati 20 by looking at the influence of VAIC on bank profitability represented by ROA without considering other variables. The next step looks at how VAIC influences if the size variable is taken into account. The third step looks at the influence of the components of VAIC namely HCE, SCE and CEE on ROA without considering other variables. The final step analyzes how the effect of HCE, SCE, and CEE on ROA takes into account variable size.

Based on the steps above, the Equations in this study can be arranged as follows:

$$
\begin{aligned}
& R O A_{i t}=\beta_{0}+\beta_{1} V_{A I C} i j, t-1 \\
& R O A_{i t}=\varepsilon_{0}+\beta_{1} V_{i t}
\end{aligned}
$$

$$
R O A_{i t}=\beta_{0}+\beta_{1} V_{A I C}+\beta_{2} \operatorname{LnTA} A_{i t}+\varepsilon_{i t}
$$

$R_{0 A} A_{i t}=\beta_{0}+\beta_{1}$ VAIC $_{i t}+\beta_{2} \operatorname{LnTA}_{i t}+$ $\beta_{3} R \& D_{i t}+\varepsilon_{i t}$

\section{(Model2)}

$R O A_{i t}=\beta_{0}+\beta_{1} H C E_{i t}+\beta_{2} S C E_{i t}+$ $\beta_{3} C E E_{i t}+\varepsilon_{i t}$

$R O A_{i t}=\beta_{0}+\beta_{1} H C E_{i t}+\beta_{2} S C E_{i t}+$ $\beta_{3} C E E_{i t}+\varepsilon_{i t}$

(Model3)

$R O A_{i t}=\beta_{0}+\beta_{1} H C E_{i t}+\beta_{2} S C E_{i t}+\beta_{3} C E E_{i t}+\beta_{4} \ln T A_{i t}+\varepsilon_{i t}$ $R O A_{i t}=\beta_{0}+\beta_{1} H C E_{i t}+\beta_{2} S C E_{i t}+$ $\beta_{3} C E E_{i t}+\beta_{2} L n T A_{i t}+\beta_{3} R \& D_{i t}+\varepsilon_{i t}$

\section{(Model4)}

The variables used in equations 1, 2,3 and 4 are described in Table 2. 
AGREGAT: Jurnal Ekonomi dan Bisnis

Vol. 3, No. 1, Maret 2019

http://journal.uhamka.ac.id/index.php/agregat

p-ISSN: 2549-5658 e-ISSN: 2549-7243

DOI: 10.22236/agregat_vol3/is1pp17-24

Hal 21

Table 2. Explanation of Variables

\begin{tabular}{|l|l|l|}
\hline \multicolumn{2}{|l|}{ Dependent Variable } \\
\hline ROA & EAT/(TA $\left.{ }_{\mathrm{t}}-\mathrm{TA}_{\mathrm{t}-1}\right) / 2$ & (Ozkan et al., 2017) \\
\hline Independent Variables & \multicolumn{2}{|l|}{} \\
\hline VAIC & CEE + HCE + SCE & (Ozkan et al., 2017; Pulic, 2004; Ullum, 2016, 2017) \\
\hline HCE & VA/HC & (Ozkan et al., 2017; Pulic, 2004; Ullum, 2016, 2017) \\
\hline CEE & VA/CE & (Ozkan et al., 2017; Pulic, 2004; Ullum, 2016, 2017) \\
\hline SCE & VA/SC & (Ozkan et al., 2017; Pulic, 2004; Ullum, 2016, 2017) \\
\hline Size & Ln Total Asset & (Djalilov \& Piesse, 2016) \\
\hline
\end{tabular}

\section{REGRESSION AND HYPOTHESIS}

The regression model to be tested is divided into 2 groups, namely: models 1 and 2 examine the relationship between VAIC and bank financial performance (ROA); Models 3 and 4 examine the relationship between IC components, namely HCE, SCE and CEE on financial performance (ROA). Equations 2 and 4 involve variable size, to see if the variable size has a different impact on financial performance (ROA).

Based on the calculation of SPSS (the results in the appendix) the following equation is obtained. The hypotheses formed from the four models are:

H1. There is a positive significant relationship between the coefficient of value-added intellectual capital (VAIC) and financial performance (ROA).

$\mathrm{H} 2$. There is a positive significant relationship between the capital employed efficiency coefficient (CEE) and financial performance (ROA).

H3. There is a positive significant relationship between the coefficients of human capital efficiency (HCE) and financial performance (ROA).

H4. There is a positive significant relationship between the coefficient of structural capital efficiency (SCE) and financial performance (ROA).

\section{RESULTS AND DISCUSSION}

The results of processing data using SPSS are summarized in the following Table 3:

Table 3. Inter Variable Correlation (according to the Pearson Corelation)

\begin{tabular}{|c|c|c|c|c|c|c|}
\hline & ROA & CEE & HCE & SCE & VAIC & LNTV \\
\hline $\mathrm{ROA}$ & 1 & & & & & \\
\hline CEE & $0.706^{* *}$ & 1 & & & & \\
\hline $\mathrm{HCE}$ & $0.471 * *$ & 0.222 & 1 & & & \\
\hline SCE & $0.448 * *$ & 0.227 & $0.958 * *$ & 1 & & \\
\hline VAIC & $0.528 * *$ & $0.319^{*}$ & $0.994 * *$ & $0.968 * *$ & 1 & \\
\hline LNTV & $0.553 * *$ & 0.122 & $0.540 * *$ & $0.522 * *$ & $0.939 * *$ & 1 \\
\hline
\end{tabular}

From the table above shows that the variables VAIC, HCE, 
SCE and size have a significant relationship to the significance value of $1 \%$ towards the
ROA variable. Specifically, the CEE variable has a significant relationship at the significance values of $1 \%$ and $5 \%$.

Table 4. Regression

\begin{tabular}{|c|c|c|c|c|}
\hline & MODEL 4 & MODEL 3 & MODEL 2 & MODEL 1 \\
\hline C & $\begin{array}{l}0.000 \\
(-5.138)\end{array}$ & $\begin{array}{l}0.009 \\
(-0.2717)\end{array}$ & $\begin{array}{l}0.010 \\
(-2.689)\end{array}$ & $\begin{array}{l}0.095 \\
(0.226) \\
\end{array}$ \\
\hline VAIC & - & - & $\begin{array}{l}0.021 \\
(2.381) \\
\end{array}$ & $\begin{array}{l}0.021 \\
(2.381) \\
\end{array}$ \\
\hline CEE & $\begin{array}{l}0.000 \\
(7.961)\end{array}$ & $\begin{array}{l}0.000 \\
(6.653)\end{array}$ & - & - \\
\hline HCE & $\begin{array}{l}0.347 \\
(0.950) \\
\end{array}$ & $\begin{array}{l}0.157 \\
(1.438) \\
\end{array}$ & - & - \\
\hline SCE & $\begin{array}{l}0.545 \\
(-0.610) \\
\end{array}$ & $\begin{array}{l}0.664 \\
(-0.437) \\
\end{array}$ & - & - \\
\hline LNTV & $\begin{array}{l}0.000 \\
(4.576)\end{array}$ & - & $\begin{array}{l}0.008 \\
(2.776)\end{array}$ & - \\
\hline $\mathrm{R} 2$ & 0.705 & 0.578 & 0.354 & 0.264 \\
\hline $\mathrm{F}$ & 30.321 & 23.334 & 14.453 & 18.600 \\
\hline$p-v$ & 0.000 & 0.000 & 0.000 & 0.000 \\
\hline
\end{tabular}

Data numbers in parentheses show the results of $t$ statistics.

Table 4 illustrates the relationship between profitability and intellectual capital from the regression equation $1,2,3,4$. The regression results show $r$ square models 3 and 4 (0.578 and 0.705) higher than models 1 and 2 (0.264 and 0.354). These results indicate that the components of VAIC are partially higher than VAIC itself ((Al-Musalli \& Ismail, 2012; Joshi et al., 2010; Ozkan et al., 2017).

The results of model 1 and 2 show that VAIC is significantly positively related to ROA. Increased VAIC will increase bank profitability. The results of models 3 and 4 show the relationship between components of VAIC (CEE and HCE) positively and significantly associated with ROA. Increased VAIC will increase bank profitability. Model 3 and 4 focus on the relationship of components of VAIC namely HCE, CEE and SCE to ROA. The results of statistical calculations show a positive relationship between CEE and HCE on ROA, an increase in CEE or HCE will increase ROA. The impact of increasing ROA due to an increase in CEE outweighed the increase in ROA due to an increase in HCE. CEE has a greater influence than HCE and SCE. These results indicate 
AGREGAT: Jurnal Ekonomi dan Bisnis

Vol. 3, No. 1, Maret 2019

http://journal.uhamka.ac.id/index.php/agregat

p-ISSN: 2549-5658 e-ISSN: 2549-7243

DOI: $10.22236 /$ agregat_vol3/is1pp17-24

Hal 23

that the banking sector uses their financial and physical assets efficiently in an effort to achieve a higher level of profitability.

\section{CONCLUSION}

The research was conducted on banks in Indonesia which became the top 10 banks in Indonesia that have large assets. This study found that CE, HCE and SCE had a significant positive relationship to the profitability of banks that had the largest number of assets in Indonesia. Of the three components CEE has the strongest relationship. These results indicate that the banking sector uses their financial and physical assets efficiently in an effort to achieve a higher level of profitability. The larger the size of the bank has the greater the level of profitability, because the bigger the bank has greater assets. Partial measurement of intellectual capital (looking at the components of IC, namely the components of HCE, CEE and SCE) on ROA has a greater impact than if the IC measurements were carried out by themselves, namely the size of VAIC.

\section{REFERENCES}

Al-Musali, M. A. K., \& Ismail, K. N. I. K. (2014). Intellectual Capital and its Effect on Financial Performance of Banks: Evidence from Saudi Arabia. Procedia - Social and Behavioral Sciences, 164, 201-207. doi:10.1016/j.sbspro.2014.11.068

Al-Musalli, M. A. K., \& Ismail, K. N. I. K. (2012). Intellectual Capital Performance and Board Characteristics of GCC Banks. Procedia Economics and Finance, 2, 219-226. doi:10.1016/ s2212-5671(12)00082-2

Berzkalne, I., \& Zelgalve, E. (2014). Intellectual Capital and Company Value. Procedia - Social and Behavioral Sciences, 110, 887-896. doi:10.1016/j.sbspro.2013.12.934

Dietrich, A., \& Wanzenried, G. (2011). Determinants of bank profitability before and during the crisis: Evidence from Switzerland. Journal of International Financial Markets, Institutions and Money, 21(3), 307-327. doi:10.1016/j. intfin.2010.11.002

Djalilov, K., \& Piesse, J. (2016). Determinants of bank profitability in transition countries: What matters most? Research in International Business and Finance, 38, 69-82. doi:10.1016/j.ribaf.2016.03.015

Edvinson, k. (2001). Intellectual capital : from intangible assets to ftness landscape.

Hashim, M. J., Osman, I., \& Alhabshi, S. M. (2015). Effect of Intellectual Capital on Organizational Performance. Procedia - Social and Behavioral Sciences, 211, 207-214. doi:10.1016/j.sbspro.2015.11.085

Joshi, M., Cahill, D., \& Sidhu, J. (2010). Intellectual capital performance in the banking sector. Journal of Human Resource Costing \& Accounting, 14(2), 151-170. doi:10.1108/14013381011062649

Lucey, B. M., Vigne, S. A., Ballester, L., 
Barbopoulos, L., Brzeszczynski, J., Carchano, O., . . . Zaghini, A. (2018). Future directions in international financial integration research - A crowdsourced perspective. International Review of Financial Analysis, 55, 35-49. doi:10.1016/j.irfa.2017.10.008

Meles, A., Porzio, C., Sampagnaro, G., \& Verdoliva, V. (2016). The impact of the intellectual capital efficiency on commercial banks performance: Evidence from the US. Journal of Multinational Financial Management, 36, 64-74. doi:10.1016/j.mulfin.2016.04.003

Mondal, A., \& Ghosh, S. K. (2015). A Study on Effectiveness of Investment in Intellectual Capital of Indian Knowledge Companies. International Journal of Business Analytics and Intelligence, 3(2). doi:10.21863/ijbai/2015.3.2.012

Ozkan, N., Cakan, S., \& Kayacan, M. (2017). Intellectual capital and financial performance: A study of the Turkish Banking Sector. Borsa Istanbul Review, 17(3), 190-198. doi:10.1016/j. bir.2016.03.001

Pasiouras, F., \& Kosmidou, K. (2007). Factors influencing the profitability of domestic and foreign commercial banks in the European Union. Research in International Business and Finance, 21(2), 222-237. doi:10.1016/j.ribaf.2006.03.007
Pulic, A. (1998). Measuring the performance of intellectual potential in knowledge economy.

Pulic, A. (2004). Intellectual capital - does it create or destroy value? Measuring Business Excellence, 8(1), 62-68. doi:10.1108/13683040410524757

Saif. (2018). The impact of bank competition and concentration on bank risk-taking behavior and stability: Evidence from GCC countries. The North American Journal of Economics and Finance. doi:10.1016/j.najef.2018.10.015

Santos, D. F. L., Basso, L. F. C., \& Kimura, H. (2018). The trajectory of the ability to innovate and the financial performance of the Brazilian industry. Technological Forecasting and Social Change, 127, 258-270. doi:10.1016/j. techfore.2017.09.027

Sumedrea, S. (2013). Intellectual Capital and Firm Performance: A Dynamic Relationship in Crisis Time. Procedia Economics and Finance, 6, 137-144. doi:10.1016/s2212-5671(13)00125-1

Ullum, I. (2016). Intellectual Capital Performance: A Comparative Study between Financial and Non-Financial Industry of Indonesian Biggest Companies.

Ullum, I. (2017). Modified_value-added_intellectual_coeffiicient (MVAIC). 